\title{
Association of methylenetetrahydrofolate reductase C677T CT gene polymorphism with a non-dipping blood pressure pattern in morbidly obese patients
}

\author{
(D)Rea Levicki1*, \\ (i) Martina Lovrić \\ Benčić ${ }^{2,3}$ \\ (D) Martina Matovinović ${ }^{2,3}$, \\ (iDLada Bradić ${ }^{\text {, }}$ \\ (D) Kristina Gašparovićc ${ }^{2,3}$, \\ (1)Tamara Božina ${ }^{3}$, \\ (iD) Nada Božina ${ }^{2,3}$, \\ (D)Jadranka Sertić ${ }^{2,3}$, \\ (DB)Bojan Jelaković ${ }^{2,3}$ \\ 'Požega General County \\ Hospital, Požega, Croatia \\ 2University Hospital Centre \\ Zagreb, Zagreb, Croatia \\ 3University of Zagreb School \\ of Medicine, Zagreb, Croatia
}

RECEIVED:

December 4, 2020

ACCEPTED:

December 18, 2020

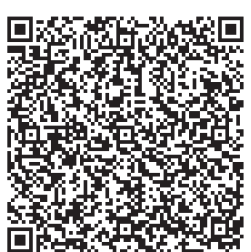

$\square$ Cardiologia Croatica 2021:16(1-2):38.

\begin{abstract}
KEYWORDS: MTHFR C677T polymorphisms, arterial hypertension, non-dipper.
CITATION: Cardiol Croat. 2021;16(1-2):38-39. | https://doi.org/10.15836/ccar2021.38
\end{abstract}

*ADDRESS FOR CORRESPONDENCE: Rea Levicki, Opća županijska bolnica Požega, Osječka 107, HR-34000 Požega, Croatia. / Phone: +385-98-550-309 / E-mail: rlevicki@gmail.com

ORCID: Rea Levicki, https://orcid.org/0000-0003-3687-1310 • Martina Lovrić Benčić, https://orcid.org/0000-0001-8446-6120 Martina Matovinović, https://orcid.org/0000-0002-6325-7394 • Lada Bradić, https://orcid.org/0000-0001-8296-699X Kristina Gašparović, https://orcid.org/0000-0002-1191-4831 • Tamara Božina, https://orcid.org/0000-0001-5883-7979 Nada Božina, https://orcid.org/0000-0001-6016-1699 • Jadranka Sertić, https://orcid.org/0000-0001-9581-9489 Bojan Jelaković, https://orcid.org/0000-0002-2546-4632

|IIIIIIIIIIIIIIIIIIIIIIIIIIIIIIIIIIIIIIIIIIIIIIIIIIIIIIIIIIIIIIIIIIIIIIIIIIIIIIIIIIIIIIIIIIIIIIIIIIIIIIIIIIIIIIIIIIIII

Introduction: Region near the gene encoding methylenetetrahydrofolate reductase (MTHFR) is associated with blood pressure. CT and TT genotype of the C677T MTHFR gene are more common in obese hypertensive patients with BMI $>29 \mathrm{~kg} / \mathrm{m}^{2}{ }^{1,2}$ The aim of this study was to prove the connection between C667T polymorphism of MTHFR gene and non-dipping pattern in $24 \mathrm{~h}$ ambulatory blood pressure monitoring (ABPM) in obese patients.

Patients and Methods: We included 33 patients from a multidisciplinary weight management program in which genetic analysis on MTHFR gene polymorphism was tested and 24h ABPM was performed. Patients were divided into 3 groups: 12 patients with MTHFR C677T healthy genotype CC ( $9 \mathrm{~W}, 3 \mathrm{M}$, age $48.83 \pm 9.82 \mathrm{y}$, BMI $\left.44.39 \pm 9.69 \mathrm{~kg} / \mathrm{m}^{2}\right)$, 14 patients with MTHFR C677T heterozygous mutation CT (11 W, 3 M, age $47.93 \pm 8.74 \mathrm{y}$, BMI $40.9 \pm 5.96 \mathrm{~kg} / \mathrm{m}^{2}$ ), 7 patients with MTHFR C677T homozygous mutation TT ( $6 \mathrm{~W}$ $1 \mathrm{M}$, age $43.43 \pm 12.22 \mathrm{y}, \mathrm{BMI} 37.46 \pm 5.79 \mathrm{~kg} / \mathrm{m}^{2}$ ). In each group $24 \mathrm{~h} A B P M$ results were analyzed, and dipping status was determined according to percentage of night systolic blood pressure drop and divided into 4 groups: inverse dipper ( $<0 \%$, non-dipper $(0-10 \%)$, dipper $(10-20 \%)$, extreme dipper $(>20 \%)$.

Results: Patients with MTHFR C677T: CT had the lowest average night blood pressure drop (8.51 $\pm 5.9 \%)$,

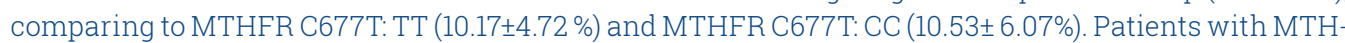
FR C677T:CT (Figure 1) were the only group with inverse dipper pattern present, but also with significant non-dipping pattern (inverse dipper 7.1\%, non-dipper 35.7\%, dipper 57.1\%) comparing to patients with MTHFR C677:TT (non-dipper 28.6\%, dipper 71.4\%) (Figure 2). Patients with MTHFR C677T:CC (Figure 3) had the highest level of dipper pattern, but also extreme dipper patter was present (non-dipper $25 \%$, dipper $66.7 \%$, extreme dipper $8.3 \%$.

\section{MTHFR C677T CT}

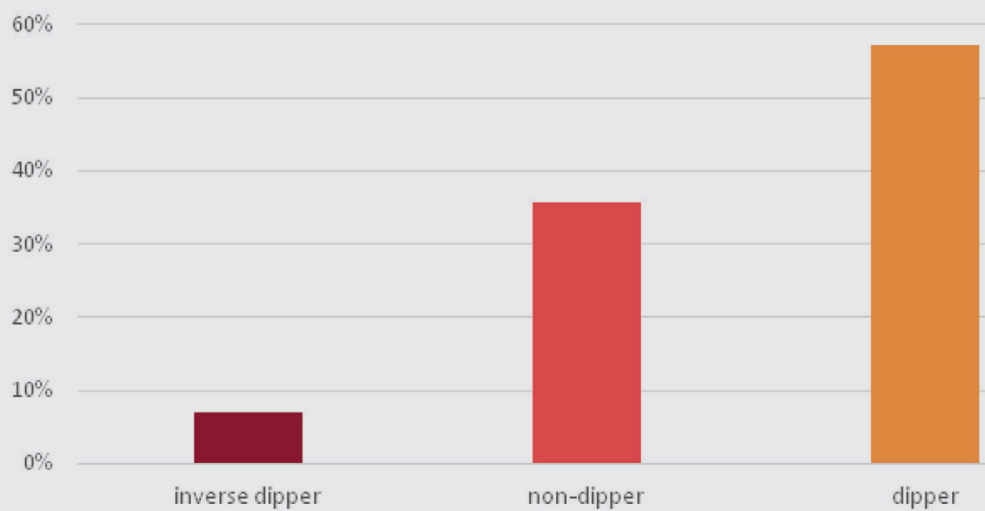

FIGURE 1. Dipping status distribution in patients with MTHFR C677T heterozygous CT mutation. 


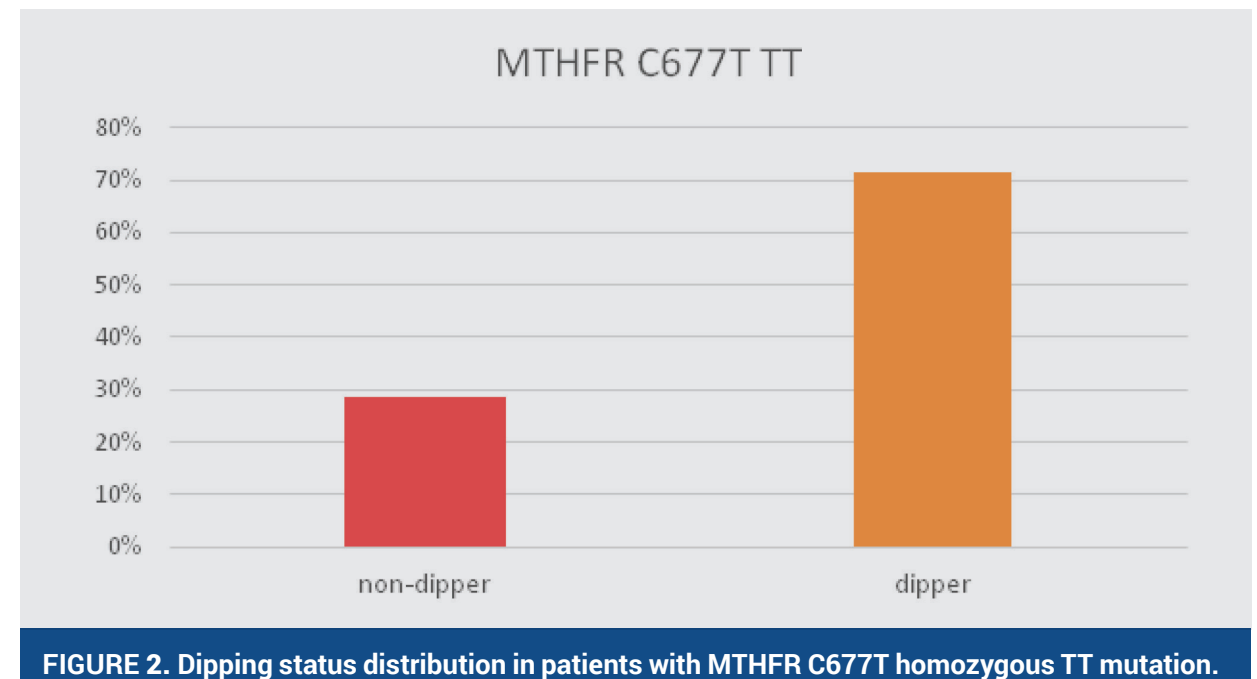

FIGURE 2. Dipping status distribution in patients with MTHFR C677T homozygous TT mutation.

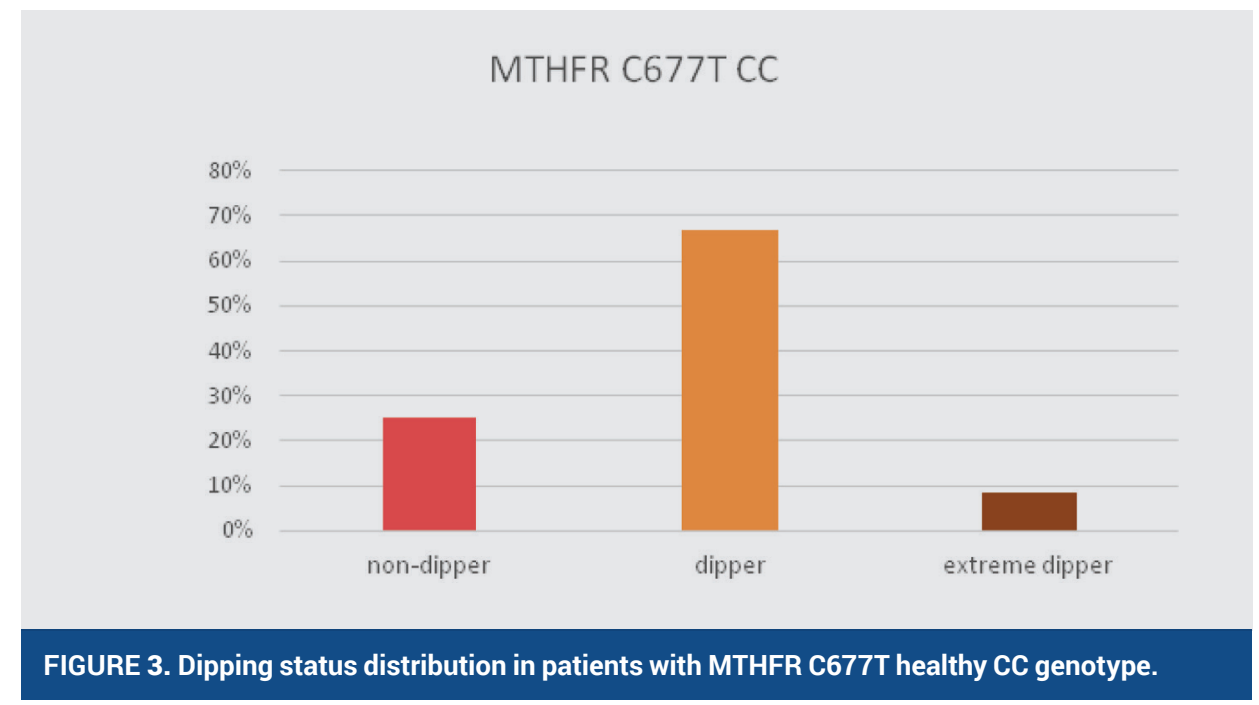

Conclusion: MTHFR C677T:CT polymorphism is the most associated with pathological patterns in dipping status; non-dipper and inverse dipper status, more than MTHFR C677T:TT, what indirectly indicates higher cardiovascular risk.

LITERATURE IIIIIIIIIIIIIIIIIIIIIIIIIIIIIIIIIIIIIIIIIIIIIIIIIIIIIIIIIIIIIIIIIIIIIIIIIIIIIIIIIIIIIIIIIIIIIIIIIIIIIIIIIIIIIIIIIIIIIIIIIIIIIIIIIIIIIIIII

1. McNulty H, Strain JJ, Hughes CF, Ward M. Riboflavin, MTHFR genotype and blood pressure: A personalized approach to prevention and treatment of hypertension. Mol Aspects Med. 2017 Feb:53:2-9. https://doi.org/10.1016/j.mam.2016.10.002

2. Pavlova OS, Ogurtsova SE, Liventseva MM, Korobko IY, Mrochek AG. [Arterial Hypertension and Methylenetetrahydrofolate Reductase C677T Gene Polymorphism]. Kardiologiia. 2018 Oct;:(10):5-11. Russian. PubMed: https://pubmed.ncbi.nlm.nih.gov/30359211/ 